\title{
Comparative Analysis of English and Albanian Body Idioms
}

\author{
Arben Gaba* \\ "Eqrem Çabej” University, Albania, Department of Foreign Languages, English Branch, Faculty of Education \\ and Social Sciences \\ *Corresponding Authors: Arben Gaba, "Eqrem Çabej” University, Albania, Department of Foreign \\ Languages, English Branch, Faculty of Education and Social Sciences, Albania
}

\begin{abstract}
The purpose of this paper is to make a comparison between the various phraseological expressions that originate from the different names of body organs that are part of the basic vocabulary of English and Albanian languages, addressing such issues as whether or not there are parallel phraseological expressions between the two languages and how are different expressions translated. In order to do this we have consulted several sources. What motivated us to write this paper is the fact that a relatively high number of these words are used in phraseological expressions, so they are important in the respective cultures. Idiomatic language is human-centered, because human body serves as an important source of idioms. This probably derives from the fact that it is easier to understand an idiom if it features a part of human body because human body is an area which resonates with anyone, both physically and metaphorically. These idioms may display the philosphy of the peoples speaking both languages and serves a window into the cultures of these peoples.
\end{abstract}

Keywords: Phraseological Comparison, Parallel Phraseological Expressions, Phraseological Expressions, Worldview.

\section{INTRODUCTION}

First we would like to say something briefly about the meaning of word idiom. According to Oxford English Dictionary (the Compact edition), an idiom is "a form of expression, grammatical construction, phrase, etc., peculiar to a language; a peculiarity of phraseology approved by the usage of a language, and often having a signification other than its grammatical or logical one". In a similar vein, Crystal (1996: 163) writes that "two central features identify an idiom. The meaning of the idiomatic expression cannot be deduced by examining the meanings of the constituent lexemes. And the expression is fixed, both grammatically and lexically".

As we see the definitions mentioned are quite general and they describe an idiom in a rather concise way, and they are suitable for everyday use.

Other definitions, however shed further light on this issue. According to Sinclair (1991: 172) an idiom is "a group of two or more words which are chosen together in order to produce a specific meaning or effect in speech or writing." He also adds that "the individual words which constitute idioms are not reliably meaningful in themselves, because the whole idiom is required to produce the meaning."

According to Riehemann's (2001: 2) an idiom is an expression made up out of two or more words, at least one of which does not have any of the meanings it can have outside of the expression. Her overall idea is that no precise definition is possible because 'idiom' is a fuzzy category.

Also Fernando and Flavell (1981: 47) try to give a definition. An idiomatic construction should have the following five properties:

- its meaning is not the compositional sum of its constituents;

- it is a unit that either has a homonymous literal counterpart or at least individual constituents that are literal, although the expression as a whole would not be interpreted literally;

- it is transformationally deficient in one way or another; 
- it forms part of a set of expressions in a given language;

- it is institutionalized.

Moon (1998: 3-4) tries to give a detailed history of an idiom. According to her two main meanings of idiom distinguished in English. The first one, which is a particular manner of expressing something in language, music, art, etc., which characterizes a person or group. The second meaning of an idiom is a particular lexical collocation or phrasal lexeme, peculiar to a language. Thus in a more narrow sense an idiom is a particular kind of unit which is fixed and semantically opaque or metaphorical, or, traditionally, 'not the sum of its parts'.

\section{TYPOLOGY OF IDOM ANALYSIS}

As has been mentioned in the introduction, the corpus of idioms for this thesis has been gathered from several sources. The majority of English idioms related to body organs were found in general dictionaries or idiom dictionaries. Reference books on idioms were also used and represent an important tool in creating this database. In order to search for the Albanian idiomatic equivalents we used primarily English-Albanian Dictionary of Idioms by Ilo Stefanllari, Hippocrene Books, Inc (2000) other books include Dictionary of today's Albanian Language by Academy of Sciences of Albania (2002) plus our own intuition as a native albanian speaker. Whereas the english dictionaries included NTC's American Idioms Dictionary, 3rd edition NTC Publishing Group, the USA. Spears, A. R. (2000); Oxford Dictionary of Idioms, Second edition, Oxford University Press, 1999, 2004; Mcgraw-Hill's Essential American idioms dictionary Second edition, 2007; Thesaurus of Traditional English Metaphors Second Edition, 2002 P. R. Wilkinson. However, not all English idioms of this corpus have their idiomatic Albanian counterparts. In such cases the non-idiomatic equivalents are provided and expressed by means of paraphrase. This paper contains a total of 687 English and albanian idioms that have been analysed and sorted into the categories that show the extent of their correspondence on the semantic, lexical, grammatical and formal levels. As we previously said not all idioms have their equivalents. Nevertheless, the corpus is quite large to afford a comparison to generalize the results for our chosen field of idioms.

After detailing the make-up of the corpus, we should explain the method chosen to carry out the analysis. The essential principle we utilized to examine the idioms is correspondence. We have tried to define correspondence semantically, i.e., the comparison of idioms centres on the meaning of the idiom as a whole and such meaning is composed of the meanings of its individual members. With most idioms in the corpus, the most important member of the idiom is a noun consequently the comparison concerns this member. The correspondence is then based on the fact whether this central component is identical in the languages chosen for comparison. Since our comparison is based on the semantic criterion those idioms which lack this key component can still be seen as corresponding providing the overall meaning of the idiom is identical. As an example, we have the English fight tooth and nail and the Albanian luftoj dhemb per dhemb (literally translated as fight tooth for tooth). These two idiomatic expressions have identical meaning, they are regarded as corresponding although the Albanian idiom lacks the word nail. Thus they are not considered totally correspondent but partially correspondent. We will try to explain such terms further below.

The selected English and albanian body idioms have been analysed and divided into the following four categories according to the level of their equivalence:

\subsection{Absolute Correspondence}

The compared idioms correspond on all three levels, i.e. on the semantic, lexical and formal level.

\begin{tabular}{|l|l|}
\hline behind sb's back & prapa shpines se dikujt \\
\hline
\end{tabular}

This category covers idioms that have the same meaning and follow the same syntactic structure of a verbal or non-verbal idiom. The English idiom behind sb's back with its albanian counterpart is an example. They use the same lexical means, the same body part and are also the same register. Keeping these things in mind we can say that these idioms are absolutely correspondent on all the three levels.

\subsection{Close Correspondence}

They are similar in meaning, use the same syntactic structure and correspond on the lexical level, nevertheless, they show small differences on the morphological level. For study purposes they are further subcategorized according to their type of deviation: 
- use of a different preposition

- use of singular vs. plural form

- use of a preposition vs. lack of it

- change of word order

a) use of a different preposition

\begin{tabular}{|l|l|}
\hline fall under sb's eye & bie ne sy te \\
\hline
\end{tabular}

Idioms belonging to this subcategory display the same syntactic structure, such as:

$\mathrm{V}+$ Prep $+\mathrm{N}$, or $\mathrm{N}+$ Prep $+\mathrm{N}$ however, the preposition used in both languages is different. The English idiom uses "under", whereas its albanian counterpart " $n \ddot{e}$ ", which means "in".

b) use of singular vs. plural form

\begin{tabular}{|l|l|}
\hline blow one's nose & shfryj hundet \\
\hline
\end{tabular}

This subcategory features a morphological deviation regarding the difference between the singular and plural form of the noun. The English idiom employs the body part "nose" which of course is singular (we do use "noses" but it is not just one body organ), while the albanian equivalent uses the same body the exception being that the word in albanian is in plural, "hundet" which means "noses"

c) use of preposition vs. lack of it

\begin{tabular}{|l|l|}
\hline pat sb on the back & I rrah krahet (shpatullat, supet) dikujt \\
\hline
\end{tabular}

This subcategory concerns the fact whether or not the same idiom employed in both languages contains a preposition. While the English idiom pat sb on the back is formed by employing a preposition, the albanian equivalent pat $s b$ 's back is formed without a preposition.

d) change of word order

\begin{tabular}{|l|l}
\hline skin and bone(s) & kocke e lekure
\end{tabular}

This subcategory shows the difference in the positon of words in an idiom. Here we see how the two languages use the same two words but the albanian idiom displays a reverse order of the nouns.

\subsection{Partial correspondence}

This group is represented by idioms which correspond only on the semantic level. They are either lexically non-equivalent or show differences in the syntactic structure. The partial correspondence can be achieved in a number of ways:

- use of a different body lexeme

- use of meronyms vs. holonyms

- use of a different verb

- use of lexically different words

- use of a lexeme vs. a compound

a) use of different body lexeme

\begin{tabular}{|l|l|}
\hline escape sb's lips & me shpeton nga goja \\
\hline
\end{tabular}

Idioms of this subcategory are characterized by different body lexemes used in both idioms. The idiom above refers to the activity of saying something unintentionally and is expressed in English by the lexeme "lips", whereas the albanian counterpart refers to "mouth".

b) use of meronyms vs. holonyms

\begin{tabular}{|l|l|}
\hline hand-to-hand fighting & lufte trup me trup
\end{tabular}

Idioms that belong to this subcategory are not equivalent in terms of the semantic relation of the body lexemes. In the English idiom a meronym body part "hand" is used, whereas the body part of the albanian idiom is formed by a holonym "body". 
c) use of different verb

\begin{tabular}{|l|l|}
\hline feast one's eyes on & kullot syte \\
\hline
\end{tabular}

This subcategory is characterized by idioms that use verbs with different denotation, although the overall meaning of the idioms is the same. Thus the English idiom employs the verb "feast", while the albanian idiom is expressed by means of the verb "graze".

d) use of lexically different words

\begin{tabular}{|l|l|}
\hline risk one's neck & rrezikoj koken \\
\hline
\end{tabular}

This subcategory contains idioms that are formed with different words. It is not limited only to the use of different body lexeme but the whole idiom is expressed by different lexical means. So the English idiom "risk one's neck" has its equivalent in albanian as "risk one's head".

e) use of a body lexeme vs. a compound

\begin{tabular}{|l|l|}
\hline presence of mind & Mendjeshkathtesi \\
\hline
\end{tabular}

Idioms that are included in this subcategory differ in the number of lexemes. Whereas albanian language shows the tendency to use compounds, in this case "agility of mind", the english idiom is formed by Noun +Prep+Noun "presence of mind".

We would like to add that all the above mentioned features which help determine the degree of correspondence between idioms are not found separately in particular idioms. Instead they can found in combination. In our paper, however, idioms are organized based on the most distinctive feature that tells idioms apart, even though they may be categorised into other subcategories.

\subsection{The Whole Idiom is Expressed with Different Lexical Means}

This subcategory includes all idioms which are formed by completely different lexical means in the two languages; however there is no change in the semantics of the idioms. That suggests that both languages employ one idiom but this idiom is in each language formed by distinct lexical elements.

As an example can serve the idiom "below/under one's breath" is contrasted with the Albanian "under voice $\backslash$ in a low voice".

\begin{tabular}{|l|l|}
\hline below/under one's breath & Nen zel Me ze le ulet \\
\hline
\end{tabular}

\subsection{Non Correspondence}

Non-correspondence is regarded as a wide category. It contains, on one hand, idioms which do not have any correspondent but it also comprises idioms which are expressed non-idiomatically. We will try to explain them below. They are concerned with possible ways of expressing idioms in other languages by using means which are not of idiomatic nature.

Here we further divide the category into subcategories which are applied for the analysis of the idioms present in the corpus of idioms collected in this paper.

\section{a) Periphrasis}

We use a periphrasis or a description to explain the meaning of an idiom if there is no idiomatic counterpart.

An example follows. The English idiom at first hand is given in Albanian by the periphrasis "from primary sources".

\begin{tabular}{|l|l|}
\hline at first hand & nga burime te drejtperdrejta \\
\hline
\end{tabular}

\section{b) One-word expression}

Instead of using an idiom the language takes advantage of employing a one-word expression of nonidiomatic nature.

As an example serves the English idiom down in the dumps $\backslash$ mouth to which corresponds to the adjective "sad".

\begin{tabular}{|l|l|}
\hline down in the dumps/mouth & $\mathrm{i}$ trishtuar \\
\hline
\end{tabular}


c) Free combination of language elements

Here we see a combination of words which would express the reality expressed by the english idiom in the closest possible way.

In the example illustrating this subcategory, Albanian use an expression "to show ingratitude" which corresponds to the English idiom "bite the hand that feeds one".

\begin{tabular}{|l|l|}
\hline bite the hand that feeds one & Tregohem mosmirenjohes \\
\hline
\end{tabular}

\section{REFERENCES}

[1] Crystal, D. (1996) The Cambridge Encyclopedia of the English Language. Cambridge: Cambridge University Press.

[2] Fernando, C. and R. Flavell. (1981) On Idiom: Critical Views and Perspectives. Exeter Lingusitic Studies. Vol. 5., pp.1-94. Exeter.

[3] Moon, R. (1998) Fixed Expressions and Idioms in English: A corpus based approach. Oxford: Clarendon Press.

[4] Riehemann, S. Z. (2001) A Constructional Approach to idioms and word formation. Dissertation, Department of linguistics, Stanford University.

[5] Sinclair, J. (1991) Corpus, Concordance, Collocation. Oxford: Oxford University Press.

[6] The Compact Edition of the Oxford English Dictionary, (1975) New York: Oxford University Press.

[7] Stefanllari, I. (2000) English-Albanian Dictionary of Idioms, Hippocrene Books, Inc

[8] Academy of Sciences of Albania (2002) Dictionary of today's Albanian Language

[9] Spears, A. R. (2000) NTC's American Idioms Diction $\neg$ ary, 3rd edition NTC Publishing Group, the USA.

[10] Oxford Dictionary of Idioms, Second edition, Oxford University Press, 1999, 2004

[11] Mcgraw-Hill's Essential American idioms dictionary Second edition, 2007

[12] P. R. Wilkinson (20000 Thesaurus of Traditional English Metaphors Second Edition

\section{English and Albanian Body Idioms}

\section{Absolute Correspondence}

\begin{tabular}{|l|l}
\hline behind sb's back & prapa shpines se dikujt
\end{tabular}

all ears/eyes gjilhe, tere sy e veshe

armed to the teeth armatosur deri ne dhembe

at heart ne zemer, ne shpirt; ne thelb

at sight me te pare; ne shikimin e pare

at somebody's hands ne duart e

bear/keep sb/sth in mind kam parasysh

beat one's brains vras mendjen

beat one's breast rrah gjoksin, i bie gjoksit me grushte

besoj vesheve (syve) o I could hardly believe my ears when I heard that Davis had married again.

bite one's lip kafshoj buzen, ha buzen me dhembe

bite one's tongue kafshoj gjuhen

blow one's brains out hedh trute ne ere, vras veten (me plumb ne koke)

bother one's head about vret (lodh) mendjen

break one's heart ia thyej zemren dikujt, ia copetoj zemren, ia bej zemren cope

break one's neck thyej qafen; veproj me ngut, me rrembim

bridle one's tongue i ve fre gjuhes (gojes)

by hand me dore

change hands nderron duar, ndryshon pronar, kalon nga dora ne dore

International Journal of Humanities Social Sciences and Education (IJHSSE) 
change one's mind nderroj mendje (mendim)

chill sb's blood i ngrij gjakun

chuck sb under the chin cek, lemoj gushen e (ne shenje perkedheljeje, dashurie etj.)

clear one's/sb ' s head kthjelloj mendjen

clear one's throat kruaj (pastroj) zerin (gurmazin)

clench one's teeth/fists etc. shtrengoj dhembet (grushtat) etj.

clip sb's wings i pres krahet; i lidh duart (krahet)

close one's ear to bej veshin e shurdher, nuk ia ve veshin

close one's eyes to mbyll syte para

cock an/one's ear(s) ngre veshet

come to hand vjen, bie ne dore

come to sb's ear(s) degjoj, me kap (me ze veshi)

crouch one's back before sb kerrus (ul, perkul) shpinen (kurrizin) para

cudgel one's brains vras mendjen

curl one's lips ngerdheshem, perdredh buzet

fall into sb's hands bie ne duart e

fall on deaf ears bie ne vesh te shurdher

hang by a hair/thread varet ne nje qime, varet ne fije (fill) te perit (te flokut)

have a heart of stone e ka zemren gur

have sth at one's fingertips e di (e njoh) ne maje te gishtave

have sth on/at the tip of one's tongue e kam ne maje te gjuhes

lick one's chops/lips lepin buzet, mprihet per te shtene ne dore dicka

new/fresh blood gjak i ri

not/never bat an eyelid nuk i ben syri terr, nuk i dridhet (nuk i luan) qerpiku (qepalla, bebja e syrit)

on the tip of one's tongue ne maje te gjuhes

open one's eyes (to) i hap (cel) syte dikujt

open one's heart to sb ia hap zemren dikujt

open one's mouth hap gojen

put sth into sb's head fus ne koke

rack one's brain(s) vras (lodh) mendjen

raise one's hand against ngre doren kunder

raise one's voice against ngre zerin kunder

seal one's lips/mouth mbyll (kyc) gojen

sell one's soul (to the devil) ia shes shpirtin shejtanit (djallit)

set foot in/on shkel, ve kemben ne

soil one's hands ndyj duart o He refused to soil his hands.

\section{The Whole Idiom is Expressed with Different Lexical Means}

\begin{tabular}{|l|l|}
\hline below/under one's breath & Nen ze $\backslash$ Me ze le ulet \\
\hline
\end{tabular} 
at the top of one's voice ne kupe te qiellit, me sa ka ne koke, me sa fuqi qe ka

fly in the face of sth shperfill me qellim; kundershtoj, veproj kunder; eshte ne kundershtim me gain/get the upper hand (over sb) 1. fitoj (kam) epersi; dal fitimtar; mund

wet behind the ears i ka buzet me qumesht, i papjekur, s'ka pervoje

\section{Close Correspondence}

use of a different preposition

\begin{tabular}{|l|l|}
\hline fall under sb's eye & bie ne sy te \\
\hline
\end{tabular}

arm in arm krah per krah

hand in hand dore per dore

stab in the back i ngul thiken prapa kurrizit, godas prapa shpine

use of singular vs. plural form

\begin{tabular}{|l|l|}
\hline blow one's nose & shfryj hundet \\
\hline
\end{tabular}

make sb's flesh creep/crawl bej t'i ngjethet mishte

use of preposition vs. lack of it

\begin{tabular}{|l|l}
\hline pat sb on the back & I rrah krahet (shpatullat, supet) dikujt
\end{tabular}

bang one's head against a brick wall i bie murit me koke

chuck sb under the chin cek, lemoj gushen e (ne shenje perkedheljeje, dashurie etj.)

turn one's back on sb i kthej krahet dikujt

change of word order

\begin{tabular}{|l|l} 
skin and bone(s) & kocke e lekure \\
\hline
\end{tabular}

bind sb hand and foot lidh kembe e duar

\section{Partial Correspondence}

use of different body lexeme

\begin{tabular}{|l|l}
\hline escape sb's lips & me shpeton nga goja
\end{tabular}

face to face balle per balle

fight tooth and nail luftoj dhemb per dhemb, maje me maje

from top to toe/from tip to toe nga koka te kembet, koke e kembe

risk one's neck rrezikoj koken veten, ve jeten ne rrezik

save one's (own) neck/skin/hide shpetoj koken, shpetoj lekuren

show a leg ngrihem nga krevati (nga gjumi)

skin and bone(s) kocke e lekure

wring one's neck ia perdredh koken

use of meronyms vs. holonyms

\begin{tabular}{|l|l}
\hline hand-to-hand fighting & lufte trup me trup
\end{tabular}

use of different verb

\begin{tabular}{|l|l}
\hline feast one's eyes on & kullot syte
\end{tabular}

cloud one's brain/judgement turbulloj mendjen (gjykimin etj.)

turn a blind eye to sth bej nje sy qorr

turn a deaf ear to bej veshin e shurdher

International Journal of Humanities Social Sciences and Education (IJHSSE)

Page | 190 
use of lexically different words

\begin{tabular}{|l|l|}
\hline risk one's neck & rrezikoj koken
\end{tabular}

apple of one's eye drita e syve

bone of contention, a molle sherri

Non Correspondence

Periphrasis

\begin{tabular}{|l|l}
\hline at first hand & nga burime te drejtperdrejta
\end{tabular}

at second hand terthorazi, nga burime te terthorta

at the top of one's voice ne kupe te qiellit, me sa ka ne koke, me sa fuqi qe ka

body blow, a zhgenjim i rende, goditje e rende, humbje e rende

break the back of bej (kryej) pjesen me te madhe, me te veshtire

bring to a head acaroj ne kulm

bring to heel mposht, nenshtroj, bej zap

burn one's fingers digjem, e pesoj

cap in hand me nderim, plot respect (perulje, perunjesi)

cool one's heels pres gjate, le dike te prese gjate

dip one's finger in sth nderhyj, perzihem, fus hundet

down at (the) heel (s) veshur si mos me keq

gain/get the upper hand (over sb) 1. fitoj (kam) epersi; dal fitimtar; mund

get cold feet trembem, frikesohem, me dridhen Ieqet e kembeve

get in/into sb's hair ngacmoj vazhdimisht

get one's own back marr hak, hakmerrem

get one's teeth into merrem (angazhohem) seriozisht, punoj i perqendruar, jepem i teri pas

get under sb's skin ngacmoj, irritoj, I ngre nervat

give sb a free hand $i$ jap liri te plote veprimi, $i$ le dore te lire

give sb a piece of one's mind ia them cope (troc. hapur) mendimin

give sb a rap on/over the knuckles qortoj; kritikoj; ndeshkoj

give sb the cold shoulder sillem ftohte, i kthej krahet dikujt

give sb the glad eye veshtroj me dashamiresi (me sy te dashuruar)

give tongue to shpreh me ze te larte

go cap in hand kerkoj perunjesisht

hand over fist kollaj e pa hesap

hang on sb's lips/words/ on sb's every word degjoj me vemendje te madhe, perpij cdo fjale, i bej veshet pipez

hat in hand gjithe servilizem (perulesi, temena)

have a chip on one's shoulder eshte mbushur gjithe mllef

have a/one's finger in the pie kam gisht ne

have a free hand kam dore te lire, kam liri veprimi

have a good head for sth ia them per, ma pret per 
have a hand like a foot $\mathrm{i}$ ka duart e thara

have one's heart in one's mouth I ngriu zemra, i shkoi gjaku ne fund te kembeve

have one's heart in sth i kushtohem (i jepem) me shpirt

have the ball at one's feet ka rast (mundesi) te mire

hit the bull's eye i ra pikes, qelloi ne shenje, i bie ne shenje (shenjes)

hit the nail on the head $i$ bie ne shenje, i bie shenjes, i bie pikes, qelloj (godit) ne shenje

hold/keep one's head above water qendroj mbi uje;jetoj me zgrip (me te keq); i shpetoj falimentimit (borxheve etj.)

hold one's head high mbaj koken perpjete, mbahem me te madh, mbaj kryet lart, mbaj hunden perpjete.

jump down sb's throat kritikoj, i flas ashper dikujt, i hidhem persysh

jump out of one's skin hidhem perpjete (nga frika, habia etj), trembem, habitem pa mase

keep a stiff upper lip qendroj i forte, tregoj burreri, nuk e leshoj veten, tregohem (mbahem) burre

keep a straight face mbaj te qeshurit

keep one's eye on the ball perqendroj (ngulit) vcmendjen te esencialja; rri syhapur

keep one's nose clean s'perzihem ne telashe

keep one's nose to the grindstone punoj pa pushim, punoj me kembengulje, s'ngre koken nga puna

knock off one's feet befasohet, habitet shume, mbetet pa mend

let no grass grow under one's feet/not let/allow the grass (to) grow under one's feet veproj pa humbur kohe, veproj energjikisht

let the grass grow under one's feet rri duarlidhur (duarkryq)

like water off a duck's back pa efekt

live from hand to mouth rroj me te keq, me zgrip

long in the tooth i moshuar, i ka ikur mosha

make a rod for one's own back e kerkoj vele belane

make (sheep's) eyes at sb perendoj syte (per dike qe dua), e ha me sy. shikoj me dashuri

make no bones about nuk hezitoj, nuk me vjen zor; pranoj menjehere; them hapur (pa hezitim)

make sb's blood boil bej t'i hipe (t'I kerceje) gjaku ne koke

neck and crop teresisht, plotesisht, me gjithsej

neck of the woods vend, zone, rajon; rrethine

neck or nothing o fitore, o hic fare

neither hide nor hair of sb/sth gje prej gjeje; kurrgje; asnje shenje (gjurme)

old hand, an njeri me pervoje

on one's last legs mezi mbahet (qendron) ne kembe

on one's toes gati per veprim; me kernbe; gjithnje gati

pain in the neck, a njeri i bezdisshem; gje e bezdisshme

palm sb off (with sth) ia hedh

palm sb/sth off (on sb) ia ngec, ia le ne dore

pay lip service to shpreh mbeshtetjen (miratimin) vetem me fjale

pay through the nose paguaj shtrenjte, paguaj si frengu pulen

International Journal of Humanities Social Sciences and Education (IJHSSE)

Page | 192 
prey on sb's mind e mundon, ia ha (bren) shpirtin

pull in one's horns i uli veshiet, i uli pendet

pull somebody's leg tallem (me shaka)

put one's finger on ve gishtin mbi

put one's foot down kembengul, ngul kembe

put one's foot in it lajthit, bej nje gabim (gafe, budallallek, procke)

put one's hand(s) to (the plough) I pervishem (futem) punes

put one's nose in dukem, shfaqem

put one's shoulder to the wheel i ve gjoksin punes

put sb's back up nxeh, inatos; ofendoj

put sb's nose out of joint e bej me turp; turbulloj, shqetesoj; ia punoj keqas dikujt

rap sb on/over the knuckles qortoj

read sb's mind/thoughts i lexoj dikujt mendimet

rub elbows/shoulders with njihem, miqesohem, ze (lidh) miqesi me, shoqerohem; krijoj lidhje me rule of thumb regull i thjeshte empirik; metode (menyre) praktike (matjeje, vleresimi etj.)

scratch my back and I'll scratch yours njera dore Ian tjetren, te dyja lajne fytyren (faqet)

see eye to eye (with) (about/on) jam I nje mendjeje me, kam te njejtin mendim me

set one's face against sth kundershtoj, jam kunder; kundervihem

set one's teeth on edge i ngre (i prish) nervat

shot in the arm nxitje; shtyse; ndihme; frymezim; stimulim

show a clean pair of heels ua mbath (ua jap) kembeve; i bej kembet te lehta

show one's face/nose dukem, dal, shfaqem

snap one's fingers at $\mathbf{s b} / \mathbf{s t h} / \mathbf{s n a p}$ one's fingers in sb's face I. trajtoj me perbuzje (percmim)

stick one's neck/chin out ve veten ne rrezik, behem (tregohem) trim, nxjerr gjoksin, marr guximin

straight from the horse's mouth nga burim i drejtperdrejte, nga burirn I besueshem

straight from the shoulder drejtperdrejt, hapur, sinqerisht, sy nder sy

straw that breaks the camel's back pika qe mbush kupen

take sb's breath away habis, mahnis, mrekulloj, befasoj, le pa goje

there's many a slip 'twixt (the) cup and (the) lip me te thene e me te bere shkon ne mes nje lume, i tere

to a hair I. tamam, per mrekulli, ne menyre le persosur

to one's heart's content sa t'i doje qejfi, sa te doje

tread on sb's corns/toes lendoj, fyej, shkel ne kallo dike

turn up one's toes kthej kembet nga dielli, vdes

wear one's heart on one's sleeve shfaq hapur ndjenjat (emocionet)

wet behind the ears i ka buzet me qumesht, i papjekur, s'ka pervoje

work one's fingers to the bone bie cope, robtohem sa s'ka ku te shkoje me

One-word expression

down in the dumps/mouth i trishtuar

at first hand drejtperdrejt, nga burime te drejtperdrejta 
at hand 1. afer, prane

at second hand terthorazi, nga burime te terthorta

bad/poor hand at sth dorengathet, s'i vjen ndoresh

big head mendjemadh, mburravec

body and soul teresisht, me gjithcka, me gjithe shpirt, me gjithe hovin e zemres, me te githa fuqite

bring sb to his knees gjunjezoj, pergjunj, perul

bring to heel mposht, nenshtroj, bej zap

bring to mind kujtoj, sjell nder mend

burn one's fingers digjem, e pesoj

by heart permendsh

by mouth/by word of mouth me goje, gojarisht

cast one's mind back kujtoj, sjell ndermend

dead from the neck up truthare, trudale, koketrashe

din in sb 's ears gumezhin, bucet, oshetin ne veshet e

do sb in the eye I. mashtroj, ia hedh sy per sy

draw blood gjakos; Jendoj, nxeh dike

draw in one's horns permbahem; terhiqem; tregohem i permbajtur; ul pendet

drive sb out of his mind/wits/senses cmend, luaj mend sh, prish nga mendte

gasp for breath 1 . gulcoj

get cold feet trembem, frikesohem, me dridhen Ieqet e kembeve

get one's fingers burnt digjem, e pesoj keq

get one's own back marr hak, hakmerrem

give sb a rap on/over the knuckles qortoj; kritikoj; ndeshkoj

hand over heart me dore ne zemer, cilterisht, ndershmerisht

have an eye to shikoj, kujdesem

head over heels/ears I. teresisht, plotesisht, deri ne gryke

keep one's mind on sth perqendrohem, kam mendjen

knock off one's feet befasohet, habitet shume, mbetet pa mend

lay/put heads together keshillohem, konsultohem, shkembej mendime

long in the tooth i moshuar, i ka ikur mosha

neck of the woods vend, zone, rajon; rrethine

one's own flesh and blood gjak, farefisni, fis, farefis

on one's knees i gjunjezuar, i pergjunjur; i perulur

pat sb on the back pergezoj, uroj, I rrah krahet (shpatullat, supet) dikujt

presence of mind mendjeshkathtesi, shkathtesi

pull a face/faces at sb ngerdheshem, shtremberoj fytyren e perdredh buzet

pull somebody's leg tallem (me shaka)

put one's foot down kembengul, ngul kembe

put one's foot in it lajthit, bej nje gabim (gafe, budallallek, procke)

International Journal of Humanities Social Sciences and Education (IJHSSE) 
put one's nose in dukem, shfaqem

put sb's back up nxeh, inatos; ofendoj

put sb's mind at ease/rest qetesoj

recall to mind kujtoj, sjell nder mend

rub elbows/shoulders with njihem, miqesohem, ze (lidh) miqesi me, shoqerohem; krijoj lidhje me set one's mind to perqendrohem, I kushtoj vemendje (kujdes) te plote, I kushtohem me zell, i ve veshin

shake a leg shpejtoj, luaj kembet

shot in the arm nxitje; shtyse; ndihme; frymezim; stimulim

straight from the shoulder drejtperdrejt, hapur, sinqerisht, sy nder sy

take a hand (in) nderhyn, angazhohet, ve dore

take the heart out of sh demoralizoj, Iigeshtoj, ia thyej zemren

throw down one's arms dorezon (hedh) armet

to a hair I. tamam, per mrekulli, ne menyre le persosur

tread on sb's corns/toes lendoj, fyej, shkel ne kallo dike

turn one's back iki, largohem, kthej krahet

turn one's hand to sth mirrem, provoj, ze me dore

with open arms krahehapur

Free combination of language elements

\begin{tabular}{|l|l}
\hline bite the hand that feeds one & Tregohem mosmirenjohes \\
\hline
\end{tabular}

bring to a head acaroj ne kulm

get cold feet trembem, frikesohem, me dridhen leqet e kembeve

get in/into sb's hair ngacmoj vazhdimisht

get it in the neck/where the chicken gets the chopper e ha keq, e ha pas qafe

get one's teeth into merrem (angazhohem) seriozisht, punoj i perqendruar, jepem i teri pas

hand in glove with so bythe e breke me, si mishi me $\mathrm{t} h$ uan, ne bashkepunim te ngushte me, lidhur ngushte me

hang heavy/heavily on one's hands mezi kalon (shtyhet) koha, etj.

have a hand like a foot $i$ ka duart e thara

have a thick skin jam i pandjeshem ndaj kritikes, e ka Iekuren e trashe, I eshte bere faqja sholle

have not a leg to stand on eshte pa baza, s'qendron

have one's head in the clouds i fluturon mendja; sheh endrra me sy cele

keep a civil tongue in one's head flas me miresjellje (me respekt, njerezishem)

keep a stiff upper lip qendroj i forte, tregoj burreri, nuk e leshoj veten, tregohem (mbahem) burre

keep a whole skin dal pa lagur, shpetoj lekuren

keep one's hand in stervis (ushtroj) doren

like water off a duck's back pa efekt $o$ Advice and correction roll off him like water off a duck's back.

make no bones about nuk hezitoj, nuk me vjen zor; pranoj menjehere; them hapur (pa hezitim) one looks as if butter wouldn't melt in one's mouth duket si qengj, duket sikur nuk turbullon uje 
pay lip service to shpreh mbeshtetjen (miratimin) vetem me fjale

see eye to eye (with) (about/on) jam I nje mendjeje me, kam te njejtin mendim me

split hairs ndan qimen katersh (dysh), kapel pas gjerave le vogla, hyn ne hollesira te panevojshme, merret me vogelima (cingerima)

twiddle one's thumbs tund (dredh) zinxhirin, rri kot, e kalon kohen kot, vrel miza

twist one's arm i perdredh krahun dikujt, detyroj (bind) dike te beje dicka

twist sb round one's little finger e sjell verdalle, e heq per hunde

use of a body lexeme vs. a compound

\begin{tabular}{|l|l} 
presence of mind & mendjeshkathtesi
\end{tabular}

big head mendjemadh, mburravec

Citation: Arben Gaba. " Comparative Analysis of English and Albanian Body Idioms" International Journal of Humanities Social Sciences and Education (IJHSSE), vol 5, no. 3, 2018, pp. 184-196. doi: http://dx.doi.org/10. $20431 / 2349-0381.0503019$.

Copyright: (C) 2018 Authors. This is an open-access article distributed under the terms of the Creative Commons Attribution License, which permits unrestricted use, distribution, and reproduction in any medium, provided the original author and source are credited. 